\title{
The effect of triacylglycerol-fatty acid positional distribution on postprandial metabolism in subcutaneous adipose tissue
}

\author{
Lucinda K. M. Summers ${ }^{1}$, Barbara A. Fielding ${ }^{1}$, Vera Ilic $^{1}$, Paul T. Quinlan ${ }^{2}$ and Keith N. Frayn ${ }^{1 *}$ \\ ${ }^{1}$ Oxford Lipid Metabolism Group, Nuffield Department of Clinical Medicine, Radcliffe Infirmary, Oxford OX2 6HE, UK \\ ${ }^{2}$ Unilever Research Colworth Laboratory, Colworth House, Sharnbrook, Bedford MK44 1LQ, UK
}

(Received 6 March 1997 - Revised 26 June 1997 - Accepted 2 September 1997)

\begin{abstract}
We hypothesized that fatty acids at the $s n-2$ position of chylomicron triacylglycerol are preferentially released into the venous plasma (rather than being taken up and stored in the adipocytes) after hydrolysis by lipoprotein lipase (EC 3.1.1.34) in adipose tissue. Arteriovenous differences across adipose tissue were studied in eight healthy subjects on two occasions for $6 \mathrm{~h}$ after ingestion of different structured triacylglycerols rich in palmitic acid either at the $s n-2$ or the $s n-1,3$ positions. In particular the specific fatty acids making up lipoprotein fractions and plasma non-esterified fatty acids were analysed. After the different meals there were no differences between either postprandial arterialized or venous plasma metabolite concentrations. Chylomicron triacylglycerol extraction in adipose tissue was the same following the two types of fat. There was no difference between the specific fatty acid composition of the postprandial non-esterified fatty acid release from adipose tissue after ingestion of the two triacylglycerols, indicating that there was no preferential release of a saturated fatty acid at the $s n-2$ position.
\end{abstract}

Triacylglycerols: Adipose tissue: Lipoprotein lipase: Postprandial metabolism

Evidence is growing that impaired postprandial triacylglycerol (TAG) metabolism may play an important role in the development of atherosclerosis (Patsch, 1994). In particular, the degree and duration of postprandial triacylglycerolaemia may be directly related to the evolution of atherogenic particles, such as small, dense LDL and loss of cholesterol from the HDL pool (Ebenbichler et al. 1995). It is of interest, therefore, to understand nutritional influences on the postprandial lipaemic response.

One such influence may be the molecular structure of dietary TAG. It has been suggested that TAG enriched with saturated fatty acids at the $s n-2$ position may be absorbed more rapidly in the gut in human infants (Filer et al. 1969; Carnielli et al. 1995) and cleared from the circulation more slowly in rats (Redgrave et al. 1988) than TAG containing saturated fatty acids at the $s n-1$ and -3 positions. TAG with a saturated fatty acid in the $s n-2$ position are not well hydrolysed by lipoprotein lipase (EC 3.1.1.34; LPL) in vitro (Tuten et al. 1993) or in vivo in rats (Mortimer et al. 1988). However, it has been shown previously that the positional distribution of fatty acids in dietary TAG has no effect on postprandial systemic plasma metabolite and hormone responses in normal adult men (Zampelas et al. 1994), suggesting that such effects are not after all important in human subjects.

Differences in the postprandial handling of dietary TAG may be more readily observed at the level of tissue metabolism. Adipose tissue is an important site for the initial hydrolysis of chylomicron TAG by LPL in the postprandial period. For some years it has been known from animal (Bergman et al. 1971; Scow, 1977) and human (Heimberg et al. 1974) studies that not all fatty acids released by the action of LPL are taken up for esterification and storage. Recent work with human subjects has shown that up to $70 \%$ of the fatty acids released by LPL action in adipose tissue were released into the venous plasma $4-5 \mathrm{~h}$ after a typical mixed meal when LPL action is maximal (Frayn et al. 1994). In the postprandial period LPL hydrolyses chylomicron TAG to release fatty acids. The fatty acids at the $s n-1$ and -3 positions are the first to be

\footnotetext{
Abbreviations: ATBF, adipose-tissue blood flow; LPL, lipoprotein lipase (EC 3.1.1.34); MAG, monoacylglycerol; NEFA, non-esterified fatty acid; SUU, structured TAG with saturated fatty acid at $s n-1,3$ position; TAG, triacylglycerol; USU, structured TAG with saturated fatty acid at $s n-2$ position; V-A, venous-arterial.
}

* Corresponding author: Dr K. N. Frayn, fax +44(0)1865 224652, email keith.frayn@oxlip.ox.ac.uk 
released. The fatty acid at the $s n-2$ position has to isomerize to the $s n-1$ or -3 position in order to be hydrolysed, or there may be uptake of the resulting 2-monoacylglycerol (MAG; Braun \& Severson, 1992). Whichever occurs, there appears to be no net production of plasma MAG during rapid LPL action in human adipose tissue in vivo (Fielding et al. 1995).

We hypothesized that, as the fatty acid at the $s n-2$ position has to isomerize to the $s n-1$ or -3 position before complete hydrolysis can occur, it will be the last chylomicron TAG-fatty acid to be hydrolysed and is likely to be released at the venous end of the adipose-tissue capillary; a fatty acid at the $s n-2$ position, therefore, may be particularly likely to enter the plasma non-esterified fatty acid (NEFA) pool. Furthermore, as saturated fatty acids at the $s n-2$ position are not well hydrolysed (Mortimer et al. 1988; Tuten et al. 1993), we hypothesized that a saturated fatty acid at the $s n-2$ position would be preferentially released into the adipose-tissue venous plasma. In order to test this hypothesis we have looked at the release of specific fatty acids into the adipose-tissue venous NEFA pool following meals containing structured TAG with a saturated fatty acid at either the $s n-1$ or -2 position. However, our experiments would equally test the opposite hypothesis of tissue uptake of the 2-MAG resulting from incomplete LPL action with preferential release of the $s n-1$ and $s n-3$ fatty acids into the plasma. The experiments also allowed us to examine the effects of TAG structure on chylomicron-TAG clearance in adipose tissue. This is the first study of the action of LPL on structured TAG in vivo in human subjects.

Some of the results have previously been published in abstract form (Summers et al. 1997) and some of the measurements of adipose-tissue blood flow (ATBF) have been presented as part of a more detailed study of blood flow regulation (Summers et al. 1996).

\section{Methods}

\section{Subjects}

Studies were conducted on eight healthy subjects (two male) aged 18-55 years (median 30.5 years), BMI 19$30 \mathrm{~kg} / \mathrm{m}^{2}$ (median $24 \mathrm{~kg} / \mathrm{m}^{2}$ ) on two occasions. Their median fasting total cholesterol concentration was 4.3 (3.3-8.2) $\mathrm{mmol} / \mathrm{l}$ with a median HDL-cholesterol concentration of $1.1(0.72-1.4) \mathrm{mmol} / \mathrm{l}$ and TAG of $1.1(0.56-3.7)$ $\mathrm{mmol} / \mathrm{l}$. Subjects were asked to refrain from smoking, alcohol and 'unaccustomed exercise' for $24 \mathrm{~h}$ before the study. They were asked to eat a fat-free meal on the evening before the study and then to fast from 20.00 hours, also avoiding caffeinated drinks. Premenopausal female subjects were studied at the same phase of their menstrual cycle on each visit. The studies were approved by the Central Oxford Research Ethics Committee and all subjects gave informed consent.

\section{Experimental methods}

A $100 \mathrm{~mm}$, 22-gauge Secalon Hydrocath catheter (Ohmeda, Swindon, UK) was introduced over a guide wire into a superficial vein on the anterior abdominal wall and threaded towards the groin so that its tip lay just superficial to the inguinal ligament. As described previously (Frayn et al. 1989), this provided access to the venous drainage from the subcutaneous abdominal adipose tissue, uncontaminated by muscle drainage and with a relatively minor contribution from skin. This adipose tissue depot has been shown to be representative of whole-body adipose tissue (Frayn et al. 1993). In one subject it proved impossible to cannulate an abdominal vein on the second attendance, so the study was continued with only arterial samples being taken and, therefore, only arterial concentrations for this subject were used in analysis of the results. Also, with two further subjects it proved impossible to obtain sufficient adipose venous samples to be able to perform analysis of the specific fatty acids in the plasma NEFA and lipoprotein fractions.

A cannula was inserted in a retrograde fashion into a vein draining a hand heated in a box at $60^{\circ}$, to provide arterialized samples. Both the arterial and the venous cannulas were kept patent by continuous infusion of isotonic saline $(9 \mathrm{~g} \mathrm{NaCl} / \mathrm{l})$. Simultaneous blood samples were taken from the arterialized vein (for simplicity, referred to as arterial) and the abdominal vein at $-20,0$, $30,60,90,120,180,240,300$ and $360 \mathrm{~min}$. A meal consisting of a milk shake with bread, containing $85 \mathrm{~g}$ carbohydrate, $60 \mathrm{~g}$ fat and $13 \mathrm{~g}$ protein was given at $0 \mathrm{~min}$. The fat consisted of a structured TAG, either predominantly with a saturated fatty acid at the $s n-1,3$ position (SUU; Unilever Research, Sharnbrook, Beds, UK) or predominantly with a saturated fatty acid at the $s n-2$ position (USU; Betapol; Unilever Research), given in random order (Table 1). ATBF was measured immediately after each blood sample using the ${ }^{133} \mathrm{Xe}$ washout method (Larsen et al. 1966) as described in Summers et al. (1996).

\section{Analyses}

A portion of each blood sample was rapidly deproteinized with perchloric acid $(70 \mathrm{~g} / \mathrm{l})$. The remainder was heparinized and was used for blood gas analysis, packed cell volume estimation (arterial samples only) and to prepare plasma. Plasma NEFA, glucose and whole-blood lactate,

Table 1. Specific fatty acid composition $(\mathrm{mol} / 100 \mathrm{~mol})$ of the total triacylglycerol (TAG) content and of the fatty acid at the sm-2 position of structured TAG with saturated fat at $s n-2$ position (USU) or $s n-1,3$ position (SUU)*

\begin{tabular}{lcclcc}
\hline & \multicolumn{2}{c}{ USU } & & \multicolumn{2}{c}{ SUU } \\
\cline { 2 - 3 } \cline { 5 - 6 } $\begin{array}{c}\text { Specific } \\
\text { fatty acids }\end{array}$ & $\begin{array}{c}\text { Fatty acid } \\
\text { composition }\end{array}$ & $\begin{array}{c}\text { Fatty acid } \\
\text { of total TAG }\end{array}$ & $\begin{array}{c}\text { Fatty acid } \\
\text { position }\end{array}$ & $\begin{array}{c}\text { composition } \\
\text { of total TAG }\end{array}$ & $\begin{array}{c}\text { Fatty acid } \\
\text { at the sn-2 } \\
\text { position }\end{array}$ \\
\hline $14: 0$ & 1.3 & 1.9 & & 1.3 & 0.4 \\
$16: 0$ & 31.1 & 67.8 & & 31.3 & 5.9 \\
$16: 1$ & 0.15 & 0.0 & & 0.3 & 0.2 \\
$18: 0$ & 1.92 & 2.7 & & 3.6 & 0.5 \\
$18: 1$ & 51.7 & 22.6 & & 50.2 & 68.2 \\
$18: 2$ & 12.6 & 3.6 & & 12.4 & 24.2 \\
$18: 3$ & 0.1 & 1.4 & & 0.2 & 0.4 \\
\hline
\end{tabular}

* Unilever Research, Shambrook, Beds., UK. 
glycerol and 3-hydroxybutyrate concentrations were measured using enzymic methods on an IL Monarch centrifugal analyser (Instrumentation Laboratory (UK) Ltd, Warrington, Cheshire, UK). Plasma TAG concentrations were also measured enzymically (with correction for free glycerol; Humphreys et al. 1990). Plasma insulin was measured in the arterial samples using a double-antibody radioimmunoassay method (Kabi Pharmacia Ltd, Milton Keynes, Bucks, UK).

Analysis of chylomicron TAG was performed at seven time points: at $0 \mathrm{~min}$ and hourly after this. VLDL-TAG analysis was performed at 0,180 and $360 \mathrm{~min}$. TAG-rich lipoprotein fractions were prepared from plasma as follows. All equipment was supplied by Beckman Instruments (UK) Ltd, High Wycombe, Bucks, UK. Chylomicron-rich fractions were prepared by layering $0.75 \mathrm{ml}$ portions of plasma underneath a solution with a density of $1006 \mathrm{~g} / \mathrm{l}$ in $11 \times 34 \mathrm{~mm}$ centrifuge tubes. The tubes were centrifuged at $4^{\circ}$ in a rotor type TLS 55 at $30000 \mathrm{rev} / \mathrm{min}$ for $20 \mathrm{~min}$ in an Optima TLX ultracentrifuge. The chylomicron-rich fraction was separated by slicing, using a 'CentriTube' tube slicer. The VLDL-rich fraction was prepared using the infranate from $1.5 \mathrm{ml}$ plasma prepared as described previously, which was transferred into $13 \times 51 \mathrm{~mm}$ belltopped centrifuge tubes and centrifuged at $4^{\circ}$ in a rotor type TLA 100.4 at $100000 \mathrm{rev} / \mathrm{min}$ for $2 \mathrm{~h} 30 \mathrm{~min}$. The VLDLrich fraction was separated by slicing using a Beckman tube slicer. The lipoprotein fractions, together with the small piece of centrifuge tube removed during slicing (to ensure recovery of any lipid adhering to the plastic), were extracted into chloroform-methanol $(2: 1, \mathrm{v} / \mathrm{v}$; Folch et al. 1956) in tubes which contained fatty acid internal standards. After separation of the lipid classes by TLC, GC (Fielding et al. 1996) was used to determine the specific fatty acid composition of the plasma NEFA, chylomicron and VLDL-TAG fractions. The absolute concentrations of the individual fatty acids were calculated by reference to internal standards; these were heptadecanoic acid for NEFA and 1,2,3-triheptadecanoyl glycerol for chylomicron TAG and VLDL-TAG. The sums of the individual fatty acids were calculated to give the total lipid concentration in each fraction. Samples of USU and SUU were also analysed using GC to establish their specific fatty acid composition (Table 1). The fatty acids at the $s n-2$ position were analysed by Unilever Research (Table 1). Overall, $76.9 \%$ of the USU TAG had a saturated fatty acid at the $s n-2$ position with unsaturated fatty acids at the $s n-1$ and -3 positions, while $57.5 \%$ of the SUU fat had a saturated fatty acid at the $s n-1,3$ position and unsaturated fatty acids at the other two positions (full species analysis is given in de Fouw et al. 1994).

\section{Calculations and statistical analyses}

ATBF was calculated as described by Larsen et al. (1966). The partition coefficient was taken as $10 \mathrm{ml} / \mathrm{g}$. Any error in the estimation of the partition coefficient should not affect analysis of the effects of feeding different TAG as individual subjects were compared with themselves. Adipose-tissue TAG fractional extraction was calculated as the arterio-venous whole-blood TAG difference divided by whole-blood arterial TAG concentration and this value was multiplied by ATBF to give TAG clearance (Potts $e t$ al. 1991). Calculation of the fate of LPL-derived fatty acids, assuming equal esterification of hormone-sensitive lipase (EC 3.1.1.3)- and LPL-derived fatty acids, has been described previously (Frayn et al. 1994).

Repeated-measures ANOVA was used to compare metabolite concentrations in each subject, analysing the effects of both the two different meals and also time. Where appropriate a paired $t$ test was used to compare maximum or minimum values with the basal value (taken as the value at $0 \mathrm{~min}$ ). Basal and postprandial areas under curves were calculated for arterial metabolite concentrations. Total area under curve was calculated for total TAG (from $0 \mathrm{~min}$ ), chylomicron TAG and VLDL-TAG extraction.

\section{Results \\ Insulin concentrations}

Arterial insulin concentrations rose significantly after both meals $(P<0.005)$, reaching a peak at 30-60 min. There was no difference in insulin concentrations between meals.

\section{Adipose tissue blood flow measurements}

As previously reported (Samra et al. 1995; Summers et al. 1996), there was a significant rise in ATBF postprandially $(P<0.005)$, with a peak at $30-60 \mathrm{~min}$. There were no significant differences in the ATBF between the two studies.

\section{Metabolite concentrations in the two sampling sites}

There were no significant differences between the two meals for either arterial or venous plasma glucose, glycerol, lactate and 3-hydroxybutyrate concentrations. Arterial concentrations are shown in Table 2. As expected, arterial glucose concentrations were slightly higher than venous concentrations throughout both experiments, but these differences were not significant (data not shown). However, the increase in both arterial and venous glucose concentrations with time after both meals was significant $(P<0.005)$, the peak occurring at $60-90 \mathrm{~min}$. Glycerol concentrations were consistently higher in the adiposetissue venous effluent than in arterial blood. Arterial and venous glycerol concentrations decreased significantly postprandially $(P<0.005)$ and were lowest at about 60 90 min following both meals. Arterial and venous lactate and 3-hydroxybutyrate concentrations also changed significantly with time $(P<0.005)$, lactate concentrations reaching a peak at $60-90 \mathrm{~min}$ and 3-hydroxybutyrate reaching a trough at $90-120 \mathrm{~min}$.

\section{Triacylglycerol}

Arterial and venous total TAG concentrations changed significantly with time $(P<0.005)$, reaching a peak at 180 $240 \mathrm{~min}$. The arterial TAG concentrations were consistently 
Table 2. Arterial metabolite concentrations for healthy subjects after meals containing structured triacylglycerol with saturated fatty acid at $s n-2$ position (USU) or $s n-1,3$ position (SUU)*

(Time-averaged values, based on mean basal and postprandial areas under curve, with their standard errors for eight subjects)

\begin{tabular}{|c|c|c|c|c|c|c|c|c|}
\hline \multirow{3}{*}{$\begin{array}{l}\text { Meal containing ... } \\
\text { Metabolite }\end{array}$} & \multicolumn{4}{|c|}{ Basal } & \multicolumn{4}{|c|}{ Postprandial } \\
\hline & \multicolumn{2}{|c|}{ SUU } & \multicolumn{2}{|c|}{ USU } & \multicolumn{2}{|c|}{ SUU } & \multicolumn{2}{|c|}{ USU } \\
\hline & Mean & SE & Mean & SE & Mean & SE & Mean & $\mathrm{SE}$ \\
\hline $\begin{array}{l}\text { Glucose }(\mathrm{mmol} / \mathrm{l}) \\
\text { Insulin }(\mathrm{mU} / \mathrm{l}) \\
\text { Lactate }(\mu \mathrm{mol} / \mathrm{l}) \\
\text { 3-Hydroxybutyrate }(\mu \mathrm{mol} / \mathrm{l}) \\
\text { Glycerol }(\mu \mathrm{mol} / \mathrm{l})\end{array}$ & $\begin{array}{c}5 \cdot 0 \\
6.3 \\
750 \\
120 \\
74.1\end{array}$ & $\begin{array}{c}0.16 \\
1.8 \\
140 \\
35 \\
7.1\end{array}$ & $\begin{array}{l}5 \cdot 0 \\
4.91 \\
640 \\
110 \\
78 \cdot 4\end{array}$ & $\begin{array}{l}0.10 \\
0.67 \\
61 \\
30 \\
8.1\end{array}$ & $\begin{array}{c}5 \cdot 3 \\
13 \cdot 6 \\
790 \\
130 \\
59 \cdot 4\end{array}$ & $\begin{array}{c}0.17 \\
2.2 \\
150 \\
37 \\
5.8\end{array}$ & $\begin{array}{c}5 \cdot 2 \\
14 \cdot 8 \\
670 \\
110 \\
65 \cdot 8\end{array}$ & $\begin{array}{c}0.10 \\
3.4 \\
64 \\
31 \\
6 \cdot 0\end{array}$ \\
\hline
\end{tabular}

" For details of subjects and procedures, see pp. 142-143 and Table 1.

higher than the venous concentrations. Adipose-tissue TAG clearance increased postprandially, being maximal at 240 min following the meal containing USU and at 180 and $360 \mathrm{~min}$ following the meal containing SUU. These increases in TAG clearance were significant $(P<0.05)$.

There were no differences between the two meals for arterial or venous total TAG (arterial values shown in Fig. 1), chylomicron TAG (Fig. 2) or VLDL-TAG concentra-

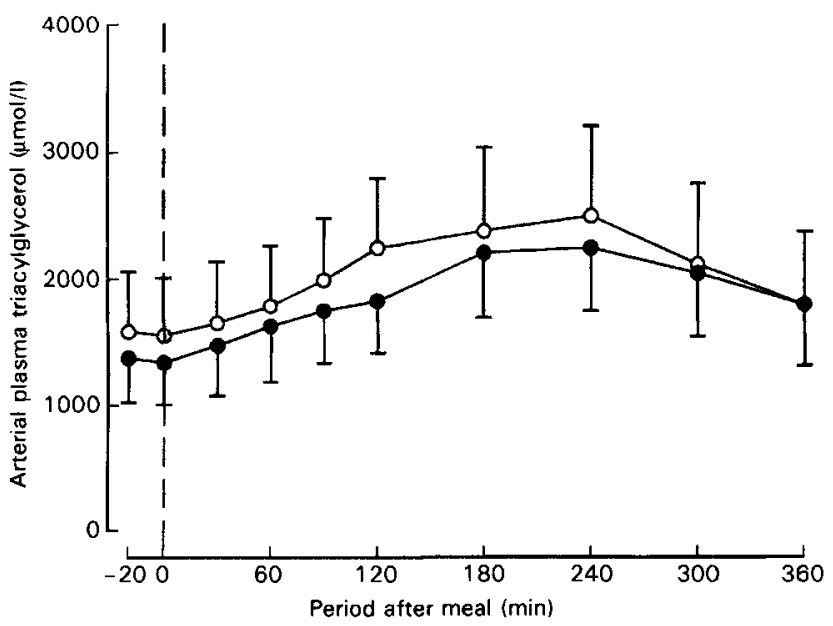

Fig. 1. Arterial total plasma triacylglycerol for eight healthy subjects after meals containing structured triacylglycerol with saturated fatty acid at $s n-2$ position $(O)$, or at $s n-1,3$ position $(\theta)$. Values are means with their standard errors represented by vertical bars. For details of subjects and procedures, see pp. 142-143 and Table 1.

Table 3. Fractional extraction of total triacylglycerol (TAG) and chylomicron TAG across adipose tissue for healthy subjects after meals containing structured TAG with saturated fatty acid at $s n-2$ position (USU) or $5 n-1,3$ position (SUU)*

(Time-averaged values, based on mean total areas under curves from $0 \mathrm{~min}$, with their standard errors for seven subjects for total TAG and for five subjects for chylomicron TAG)

\begin{tabular}{lccccc}
\hline & \multicolumn{3}{c}{ Fractional extraction (\%) } \\
\cline { 2 - 3 } Meal containing ... & \multicolumn{2}{c}{ USU } & & \multicolumn{2}{c}{ SUU } \\
\cline { 2 - 3 } \cline { 5 - 6 } & Mean & SE & & Mean & SE \\
\hline Total TAG & 6.7 & 1.0 & & 5.9 & 1.3 \\
Chylomicron TAG & 21.6 & 7.4 & & 18.8 & 8.9 \\
\hline
\end{tabular}

- For details of subjects and procedures, see pp. 142-143 and Table 1. tions (not shown). The fractional extraction of total TAG and chylomicron TAG did not differ between meals (Table 3 ). There were also no differences in total TAG or chylomicron TAG clearance between the two meals.

Chylomicron TAG (Fig. 2) and VLDL-TAG concentrations changed significantly with time at both sites $(P<0.005)$, reaching a maximum at $180 \mathrm{~min}$ after both meals. Arterial chylomicron TAG was consistently higher than adipose venous chylomicron TAG after both meals (Fig. 2). Arterial VLDL-TAG concentrations were also higher than venous concentrations for both meals. There
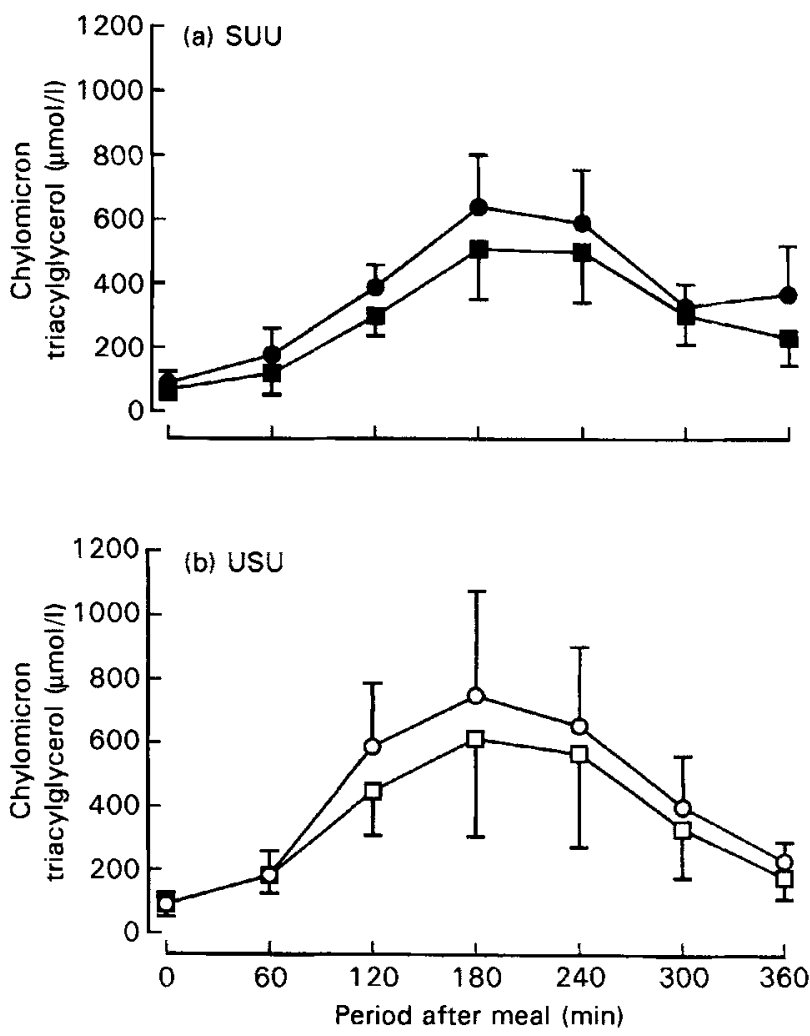

Fig. 2. Arterial $(\varphi, O)$ and venous $(\square, \square)$ chylomicron triacylglycerol or seven healthy subjects after meals containing structured triacylglycerol with (a) saturated fatty acid at $s n-1,3$ position (SUU; -, ), or (b) at $s n-2$ position (USU; $O, \square$ ). Values are means with their standard errors represented by vertical bars. For details of subjects and procedures, see pp. 142-143 and Table 1. 


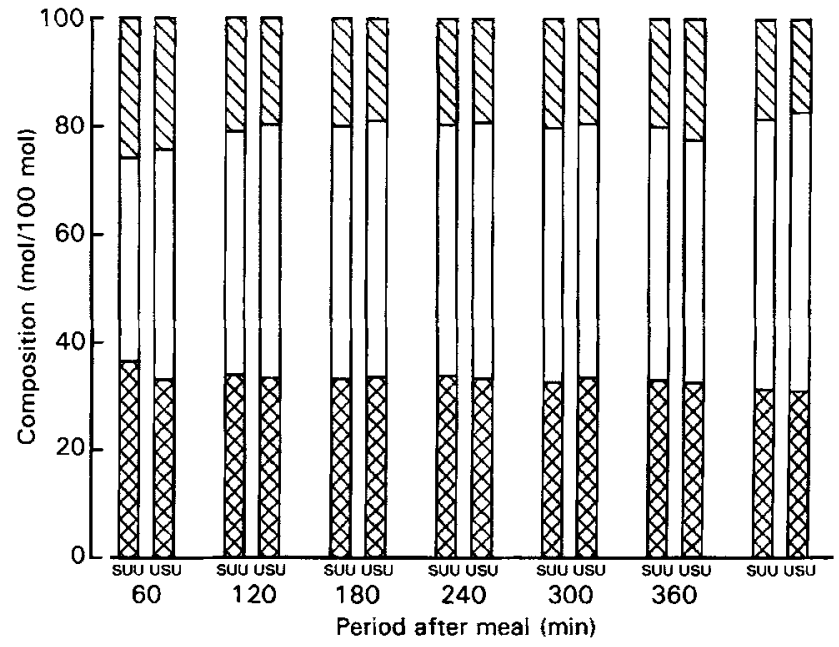

Fig. 3. Specific fatty acid composition (mol/100 mol) of arterial chylomicron triacylglycerol in eight healthy subjects compared with composition of structured triacylglycerol with saturated fatty acid at $s n-1,3$ position (SUU), or at $s n-2$ position (USU). (图), $C_{16: 0}$ ( $\square$ ), $\mathrm{C}_{18: 1} ;(\mathbb{\nabla})$, other fatty acids. For details of subjects and procedures, see pp. 142-143 and Table 1.

was no difference between the arterial and venous concentrations of palmitic and oleic acid relative to total chylomicron TAG-fatty acid content over time with either meal (Fig. 3).

\section{Non-esterified fatty acids}

NEFA concentrations at the arterial site and in the adipose venous effluent changed significantly with time $(P<0.005)$ with maximal NEFA suppression occurring at 60-90 min. As in previous mixed-meal studies (Coppack et al. 1990) there was a large venous-arterial (V-A) difference for NEFA both before and after the meal, indicating net release of fatty acid from adipose tissue. The $\mathrm{V}-\mathrm{A}$ difference changed significantly with time $(P<0.005)$ and was lowest at the times of maximal NEFA suppression (Fig. 4). There was no difference between the two meals in the V-A differences. When comparing the two meals there were no differences between arterial or venous plasma NEFA concentrations. The proportions of LPL-derived fatty acids released into the venous plasma (rather than being reesterified and stored in adipose tissue) were similar after both meals and increased significantly $(P<0.005)$ in the postprandial period, reaching a maximum of at least $70 \%$ after $4-6 \mathrm{~h}$.

There were no differences between the meals in palmitic or oleic acid concentrations in the arterial and venous plasma NEFA fractions at any time point, nor any difference in their concentrations when expressed relative to total NEFA released from adipose tissue (Table 4). There was also no difference in oleic acid: palmitic acid ratio in the $\mathrm{V}-\mathrm{A}$ difference of the plasma NEFA fraction with time following either meal and no differences between the two meals.
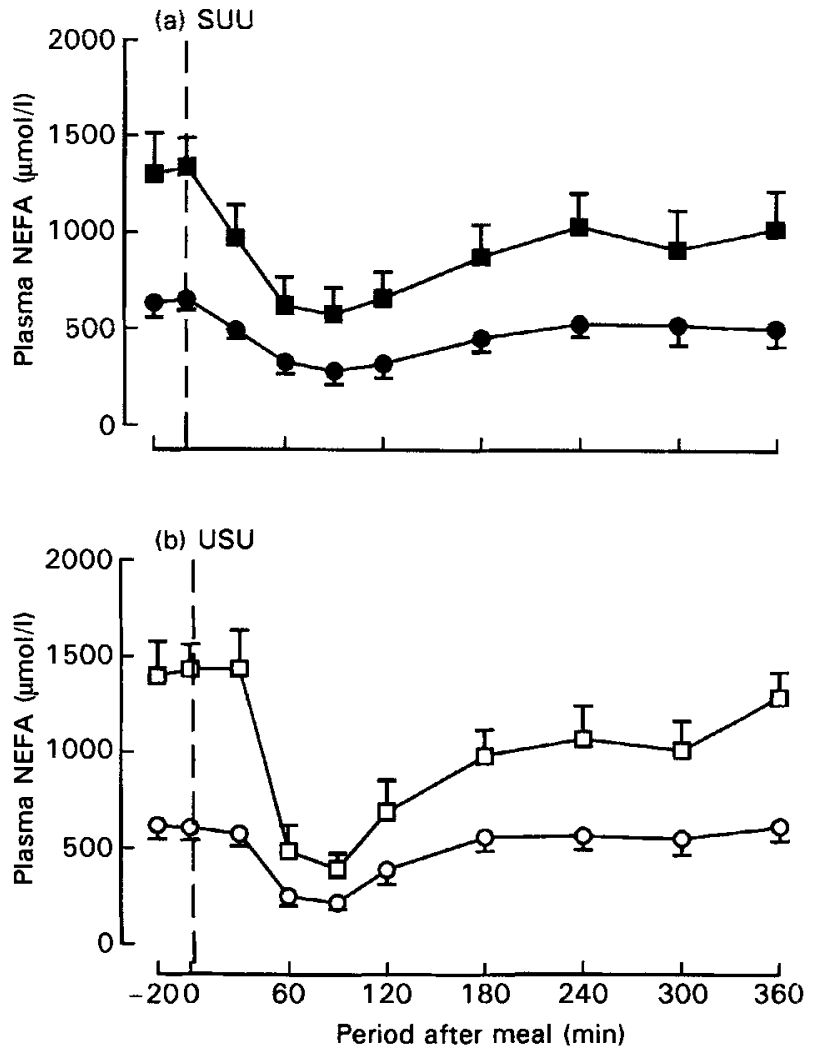

Fig. 4. Arterial $(\Theta, O)$ and venous $(\square, \square)$ plasma non-esterified fatty acids in seven healthy subjects after meals containing structured triacylglycerol with saturated fatty acid at $s n-1,3$ position (SUU; $\square$ ), or at sn-2 position (USU; $O, \square$ ). Values are means with their standard errors represented by vertical bars. For details of subjects and procedures, see pp. 142-143 and Table 1.

Table 4. Composition of total adipose-tissue non-esterified fatty acid release $(\mathrm{mol} / 100 \mathrm{~mol})$ for healthy subjects from $4-6 \mathrm{~h}$ after meals containing structured triacylglycerols with saturated fatty acid at $s n-2$ position (USU) or $s n-1,3$ position (SUU) ${ }^{*}$

(Mean values and standard deviations for five subjects)

\begin{tabular}{lccccc}
\hline \multirow{2}{*}{$\begin{array}{l}\text { Meal containing ... } \\
\text { Specific fatty acids }\end{array}$} & \multicolumn{2}{c}{ USU } & & \multicolumn{2}{c}{ SUU } \\
\cline { 2 - 3 } \cline { 5 - 6 } \cline { 5 - 6 } & Mean & SD & & Mean & SD \\
\hline $14: 0$ & 1.93 & 0.45 & & 1.37 & 2.24 \\
$16: 0$ & 28.2 & 8.07 & & 30.0 & 7.24 \\
$16: 1$ & 3.42 & 1.86 & & 3.44 & 2.66 \\
$18: 0$ & 3.66 & 1.90 & & 6.07 & 6.53 \\
$18: 1$ & 47.1 & 7.09 & & 44.0 & 7.24 \\
$18: 2$ & 15.1 & 0.76 & & 12.7 & 5.70 \\
$18: 3$ & 0.98 & 1.01 & & 1.89 & 2.64 \\
$18: 1 / 16: 0$ & 1.96 & 0.98 & 1.68 & 0.29 \\
\hline
\end{tabular}

- For details of subjects and procedures, see pp. 142-143 and Table 1.

\section{Discussion}

We have assumed that the fatty acid at the $s n-2$ position of dietary fat is mainly conserved at the same position in the chylomicron TAG. There is good evidence that this does occur in vivo. When dietary TAG is ingested it is acted on by pancreatic lipase in the small intestine to form a 2-MAG and two fatty acids. These are then taken up into the intestinal cells where chylomicron TAG is manufactured. 
There are two pathways for the production of chylomicron TAG; the phosphatidic acid pathway and the 2-MAG pathway. Following fat ingestion, most chylomicron TAG synthesis occurs via the 2-MAG pathway. In any case TAG arising by the MAG or the phosphatidic acid pathway are closely similar to each other and to the TAG ingested (Myher et al. 1987). It has been shown that at least $85 \%$ of the fatty acid at the $s n-2$ position of dietary TAG is conserved at the $s n-2$ position of chylomicron TAG following ingestion and absorption in the intestine (Åkesson et al. 1978; Yang \& Kuksis, 1991; Pufal et al. 1995).

As expected from the study by Zampelas et al. (1994) there were no differences between the arterial metabolite or insulin concentrations after the two meals. We found no difference in palmitic acid release across adipose tissue after the two meals. A power calculation shows that there is a $90 \%$ chance in this study of being able to detect a true difference of $15 \%$ between the adipose tissue $\mathrm{V}-\mathrm{A}$ palmitic acid following the different meals. Additionally, if our hypothesis that a saturated fatty acid at the $s n-2$ position of dietary TAG would be preferentially released had been correct, we would have expected to find more palmitic acid than oleic acid released into the adipose venous effluent following ingestion of USU than following ingestion of SUU. However, the oleic:palmitic acid values in the NEFA V-A difference (the NEFA released from adipose tissue) were very similar after the two meals. These results suggest that our original hypothesis was incorrect; there is no evidence that a saturated fatty acid at the $s n-2$ position was preferentially released into the adipose tissue venous plasma. However, these findings also provide strong evidence against the alternative hypothesis of tissue uptake of 2-MAG with preferential release of the $s n-1$ and $s n-3$ fatty acids into the venous plasma.

It has previously been found in rats that the plasma clearance of intravenously administered TAG-rich emulsions depends on the arrangement of the acyl chains of the constituent TAG rather than the degree of saturation (Mortimer et al. 1994). Also, it has been demonstrated with different structured TAG that there is delayed clearance of TAG containing a saturated fat at the $s n-2$ position (Mortimer et al. 1988; Redgrave et al. 1988). This experiment has demonstrated that this is not a major effect in human subjects; the stereospecific positions of the acyl chains on the structured TAG used in the meals had no measurable effect on the postprandial clearance of chylomicron TAG from the circulation.

The study depends on the assumption that hydrolysis of circulating chylomicron TAG by LPL rather than adiposetissue TAG breakdown by hormone-sensitive lipase is the major source of fatty acids leaving adipose tissue in the postprandial period. This has been shown to be true in a number of previous studies, by calculation of the estimated proportion of LPL-derived fatty acids leaving adipose tissue (Frayn et al. 1994, 1995). As expected, in the present study this increased significantly after the meals, reaching a maximum of about $70 \%$ over the $240-360 \mathrm{~min}$ period. There was no difference between the proportion of LPLderived fatty acids in the adipose venous plasma after the two meals and, although the majority of the fatty acids released resulted from the action of LPL on chylomicron TAG, the composition was strikingly constant with time and similar after the two types of fat. This argues very strongly against any selective tissue uptake or release of fatty acids according to either position within the TAG molecule or the saturation of the fatty acid molecule.

One problem with the particular structured TAG used in the present study is that palmitic and oleic acids are the most common fatty acids in the plasma NEFA fraction, making up 30 and $60 \mathrm{~mol} / 100 \mathrm{~mol}$ respectively, approximately the same proportions as in the structured TAG we gave our subjects. The fact that there were in any case such high concentrations of palmitic and oleic acid in the plasma NEFA fraction may have made it difficult to see small differences in a small number of subjects during a period of rapid metabolism where no 'steady-state' has been reached. It might be more interesting, therefore, in future work to study the effects of structured TAG containing fatty acids that are less commonly found in the plasma NEFA fraction or to use ${ }^{13} \mathrm{C}$-labelled dietary fats.

\section{Acknowledgements}

This research was performed under a contract from the Ministry of Agriculture, Fisheries and Food. Some equipment was purchased with a Realising Our Potential Award from the Medical Research Council and with a grant from the Dunrill Medical Trust. We would like to thank Mr J. S. Samra, Mrs S. M. Humphreys, Miss M. L. Clark and Mrs C. Ruhle for technical assistance and moral support.

\section{References}

Åkesson B, Gronowitz S, Herslof B \& Ohlson, R (1978) Absorption of synthetic, stereochemically defined acylglycerols in the rat. Lipids 13, 338-343.

Bergman EN, Havel RJ, Wolfe BM \& Bohmer T (1971) Quantitative studies of the metabolism of chylomicron triglycerides and cholesterol by liver and extrahepatic tissues of sheep and dogs. Journal of Clinical Investigation 50, 18311839.

Braun J \& Severson D (1992) Regulation of the synthesis, processing and translocation of lipoprotein lipase. Biochemical Journal 287, 337-347.

Carnielli VP, Luijendijk IHT, van Beek RHT, Boerma GJM, Degenhart HJ \& Sauer PJJ (1995) Effect of dietary triacylglycerol fatty acid positional distribution on plasma lipid classes and their fatty acid composition in preterm infants. American Journal of Clinical Nutrition 62, 776-781.

Coppack SW, Frayn KN, Humphreys SM, Whyte PL \& Hockaday TD (1990) Arteriovenous differences across human adipose tissue and forearm tissues after overnight fast. Metabolism 39, 384-390.

de Fouw N, Kivits GAA, Quinlan PT \& van Nielen WGL (1994) Absorption of isomeric, palmitic acid-containing triacylglycerols resembling human milk fat in the adult rat. Lipids 29 , $765-770$.

Ebenbichler CF, Kirchmair R, Egger C \& Patsch JR (1995) Postprandial state and atherosclerosis. Current Opinion in Lipidology 6, 286-290.

Fielding B, Humphreys S, Shadid S \& Frayn K (1995) Plasma mono-, di- and triacylglycerol measurements in a study of fat 
uptake by human adipose tissue in vivo. Biochemical Society Transactions 23, 487S.

Fielding BA, Callow J, Owen M, Samra JS, Matthews DR \& Frayn KN (1996) Postprandial lipemia: the origin of an early peak studied by specific dietary fatty acid intake during sequential meals. American Journal of Clinical Nutrition 63, $36-41$.

Filer LJ, Mattson FH \& Fomon SJ (1969) Triglyceride configuration and fat absorption by the human infant. Journal of Nutrition 99, 293-298.

Folch J, Lees M \& Sloane-Stanley G (1956) A simple method for the isolation and purification of total lipides from animal tissues. Journal of Biological Chemistry 226, 497-509.

Frayn KN, Coppack SW, Fielding BA \& Humphreys SM (1995) Coordinated regulation of hormone-sensitive lipase and lipoprotein lipase in human adipose tissue in vivo: implications for the control of fat storage and fat mobilization. Advances in Enzyme Regulation 35, 163-178.

Frayn KN, Coppack SW \& Humphreys SM (1993) Subcutaneous adipose tissue metabolism studied by local catheterization. International Journal of Obesity 17, S18-S21.

Frayn KN, Coppack SW, Humphreys SM \& Whyte PL (1989) Metabolic characteristics of human adipose tissue in vivo. Clinical Science 76, 509-516.

Frayn KN, Shadid S, Hamlani R, Humphreys SM, Clark ML, Fielding BA, Boland O \& Coppack SW (1994) Regulation of fatty acid movement in human adipose tissue in the postabsorptive-to-postprandial transition. American Journal of Physiology 266, E308-E317.

Heimberg M, Dunn GD \& Wilcox HG (1974) The derivation of plasma-free fatty acids from dietary neutral fat in man. Journal of Laboratory and Clinical Medicine 83, 393-402.

Humphreys SM, Fisher RM \& Frayn KN (1990) Micro-method for measurement of sub-nanomole amounts of triacylglycerol. Annals of Clinical Biochemistry 27, 597-598.

Larsen OA, Lassen NA \& Quaade F (1966) Blood flow through human adipose tissue determined with radioactive xenon. Acta Physiologica Scandinavica 66, 337-345.

Mortimer B-C, Holthouse DJ, Martins IJ, Stick RV \& Redgrave TG (1994) Effects of triacylglycerol-saturated acyl chains on the clearance of chylomicron-like emulsions from the plasma of the rat. Biochimica et Biophysica Acta 1211, 171-180.

Mortimer B-C, Simmonds WJ, Joll CA, Stick RV \& Redgrave TG (1988) Regulation of the metabolism of lipid emulsion model lipoproteins by a saturated acyl chain at the 2-position of triacylglycerol. Joumal of Lipid Research 29, 713-720.
Myher JJ, Kuksis A, Yang LY \& Marai L (1987) Stereochemical course of intestinal absorption and transport of mustard-seed oil triacylglycerols in the rat. Biochemistry and Cell Biology 65, 811-821.

Patsch JR (1994) Triglyceride-rich lipoproteins and atherosclerosis. Atherosclerosis 110 Suppl., S23-S26.

Potts JL, Fisher RM, Humphreys SM, Coppack SW, Gibbons GF \& Frayn KN (1991) Peripheral triacylglycerol extraction in the fasting and post-prandial states. Clinical Science 81, 621626.

Pufal DA, Quinlan PT \& Salter AM (1995) Effect of dietary triacylglycerol structure on lipoprotein metabolism: A comparison of the effects of dioleoylpalmitoylglycerol in which palmitate is esterified to the 2- or 1(3)-position of the glycerol. Biochimica et Biophysica Acta 1258, 41-48.

Redgrave TG, Kodali DR \& Small DM (1988) The effect of triacyl-sn-glycerol structure on the metabolism of chylomicrons and triacylglycerol-rich emulsions in the rat. Journal of Biological Chemistry 263, 5118-5123.

Samra JS, Frayn KN, Giddings JA, Clark ML \& Macdonald IA (1995) Modification and validation of a commercially available portable detector for measurement of adipose tissue blood flow. Clinical Physiology 15, 241-248.

Scow RO (1977) Metabolism of chylomicrons in perfused adipose and mammary tissue of the rat. Federation Proceedings 36, 182-185.

Summers LKM, Fielding BA, Ilic V \& Frayn KN (1997) The effect of body mass index on postprandial non-esterified fatty acid suppression. Proceedings of the Nutrition Society 56, 95A.

Summers LKM, Samra JS, Humphreys SM, Morris RJ \& Frayn KN (1996) Subcutaneous abdominal adipose tissue blood flow: variation within and between subjects and relationship to obesity. Clinical Science 91, 679-683.

Tuten T, Robinson KA \& Sgoutas DS (1993) Discordant results for determinations of triglycerides in pig sera. Clinical Chemistry 39, 125-128.

Yang LY \& Kuksis A (1991) Apparent convergence (at 2monoacylglycerol level) of phosphatidic acid and 2-monoacylglycerol pathways of synthesis of chylomicron triacylglycerols. Journal of Lipid Research 32, 1173-1186.

Zampelas A, Williams CM, Morgan LM \& Wright J (1994) The effect of triacylglycerol fatty acid positional distribution on postprandial plasma metabolite and hormone responses in normal adult men. British Journal of Nutrition 71, 401410. 